IRSH 52 (2007), pp. I 89-207 DOI: I0.10I7/S0020859007003 I 97

(C) 2007 Internationaal Instituut voor Sociale Geschiedenis

\title{
Bitter Memories and Burst Soap Bubbles: Irony, Parody, and Satire in the Oral-Literary Tradition of Finnish Working-Class Youth at the Beginning of the Twentieth Century*
}

\author{
KIRSTI SALMI- NIKLANDER
}

SUMmary: This article discusses irony, parody, and satire in the oral-literary tradition of Finnish working-class youth during the first decades of the twentieth century. The most important research material is Valistaja (The Enlightener, I9I4I925), a handwritten newspaper produced by young working-class people in the industrial town of Karkkila in southern Finland. This research material provides examples of different kinds of parody: ideological parody is directed against both political opponents and the texts representing their ideology; generic parody involves playing with linguistic norms and generic conventions. Parody and satire provided means for exposing the cruelty and cowardice of the anti-Bolshevik Whites, the hypocrisy of the Church, and the conservatism of the older generation of workers. The ironic expressions reflect the experiences and tensions among groups of young people in Karkkila.

Irony, parody, and satire have been important means of expression in movements of social protest, providing tools for ridiculing ideological opponents and for discussing inner tensions, but there has been a scarcity of systematic research into their meanings in working-class culture and the labour movement. ${ }^{\text {I }}$ In this article I discuss the meanings and functions of

* Research funding from the Emil Aaltonen Foundation enabled me to produce the manuscript of this article. Tommi Kuutsa and Janne Viitala at the Karkkila Ironworks Museum and Petri Tanskanen at the Finnish Labour Archives assisted me with the illustrations. Teija Norvanto has kindly commented on both the language and the content. My warmest appreciation goes to Ilona Kemppainen, Tarja Kupiainen, Niina Lappalainen, and Ulla-Maija Peltonen of "The Invention of Heroes" research project for their valuable comments and support. Parts of this article are based on papers presented at the tenth conference of SHARP (Society for the History of Authorship, Reading and Publishing) in London (July 2002), at the conference "Literature and its Others" (Turku, May 2003), and at the symposium "The Travelling Concept of Narrative" (Helsinki, December 2004).

I. Irony and parody have been studied to some extent in relation to humorous communication in workplaces. See Seppo Knuuttila, Kansanhuumorin mieli. Kaskut maailmankuvan aineksena (Helsinki, 1992), pp. 176-ı 88; Don Handelman and Bruce Kapferer, "Forms of Joking Activity: A Comparative Approach”, American Anthropologist, 74 (1972), pp. 484-517. Alessandro 
irony, parody, and satire in the oral-literary tradition of Finnish workingclass youth during the first decades of the twentieth century. My conclusions are based on a case study of the literary activities during the I9ros and I920s of young working-class people in Karkkila (Högfors), ${ }^{2}$ a small industrial community in southern Finland. During those decades, the young men and women of the town wrote a large collection of handwritten newspapers named Valistaja (The Enlightener, 1914-1925). ${ }^{3}$

My research method has involved multi-phased ethnographic closereading, which utilizes discourse and narrative analysis as well as intertextual analysis across the local oral tradition of Karkkila (interviews and folklore collections) as well as literary and popular culture (including broadsheets, journals, and comic songs). My theoretical framework is derived from microhistory, book history, and the folkloristic and anthropological research on orality and literacy. One of the key terms is the oral-literary local tradition, by which I mean those expressive genres that involved both oral and written communication. ${ }^{4}$ Another important term is "conversational community", which I define as a group of people in close interaction who create, adapt, and interpret texts presented in oral and literary form. The members of a conversational community are tied to each other by social or economic bonds. 5

Portelli has discussed the meanings of parody in relation to industrial work songs in The Death of Luigi Trastulli and Other Stories: Form and Meaning in Oral History (Albany, NY, I991), pp. I70-173, I76-177. The meaning of parody in the workers' tradition of the Finnish Civil War has been discussed by Ulla-Maija Peltonen in "Memoirs Concerning 'The Black Times' of the I92os and the I930s", in Flemming Hemmersam (ed.), "To Work, To Life or to Death": Studies in Working Class Lore (Copenhagen, 1996), pp. 196-218, 212-213.

2. The name Karkkila was introduced at the end of the 1920 , when the industrial community of Högfors was separated from the surrounding parish of Pyhäjärvi and became an independent township. When I am referring to the events of the nineteenth and the early twentieth centuries, I use in most cases the names Högfors and Pyhäjärvi.

3. Kirsti Salmi-Niklander, Itsekasvatusta ja kapinaa. Tutkimus Karkkilan työläisnuorten kirjoittavasta keskusteluybteisöstä 19I0- ja I920-luvuilla (Helsinki, 2004); Valistaja (19141925), Archives of the Högfors Social Democratic Youth Club (Finnish Labour Archives, Helsinki).

4. My formulation of the term is related to the ethnographical or ideological orientation of the research into orality and literacy. The researchers with ethnographic-ideological orientation concentrate on hybrid oral-literate practices ("literacies") challenging the "great-divide" model of orality and literacy. Brian V. Street, "Introduction: The New Literacy Studies”, in idem (ed.), Cross-Cultural Approaches to Literacy (Cambridge, 1993), pp. I-21, I, 8-10. See also Niko Besnier, Literacy, Emotion and Authority: Reading and Writing on a Polynesian Atoll (Cambridge, 1995), pp. 6-I 2; Amy Shuman, Storytelling Rights: The Uses of Oral and Written Texts by Urban Adolescents (Cambridge, 1986).

5. My definition of the term "a conversational community" is somewhat wider than the terms "speech community" and "performance community" discussed by folklorists. See Roger Abrahams, "After New Perspectives: Folklore Study in the Late Twentieth Century", Western Folklore, 52 (1993), pp. 379-400, 386-387; ibid., "Phantoms of Romantic Nationalism in Folkloristics", Journal of American Folklore, 106 (1993), pp. 3-37, 2 I-22. 


\section{HANDWRITTEN NEWSPAPERS AS AN ALTERNATIVE MEDIUM}

The oral-literary local tradition is closely linked to the creation of local public activity and the rise of the labour movement and other popular movements at the end of the nineteenth century. ${ }^{6}$ Popular movements have created many new scenes for the oral-literary local tradition, such as meetings, social evenings, and sports events. They have also introduced new genres of oral and written expression in local communities: members of local communities learned how to deliver speeches, conduct meetings, and write in local newspapers, whether printed or handwritten. Learning to use and interpret parody and irony was one of the skills developed in popular movements.

Handwritten newspapers were popular in families and schools throughout western Europe and North America during the nineteenth and twentieth centuries. ${ }^{7}$ In Finland they became an important alternative medium for student organizations and popular movements of the nineteenth and the early twentieth centuries, although they have scarcely been studied and have been archived only haphazardly. ${ }^{8}$ In Finland the earliest examples of handwritten newspapers date from the first decades of the nineteenth century in secondary schools and upper- or middle-class families. ${ }^{9}$ During the I 850 , handwritten newspapers became an important alternative medium for frustrated university students under the strict censorship during the rule of Tsar Nicholas I, the Grand Duke of Finland. ${ }^{\text {I० }}$ Although handwritten newspapers were published as a single copy, they could reach quite large audiences. ${ }^{\text {II }}$ They were published by being read aloud at meetings and informal gatherings. Sometimes the writers would aim their words rather at listeners than readers of the paper.

6. The term "local public activity" refers to the Swedish den lokala offentligheten formulated by Ronny Ambjörnsson in Den skötsamma arbetaren (Stockholm, I988), pp. I78-179.

7. Handwritten family papers were edited in many upper-class and intellectual families in Britain and the United States, for example by Charlotte, Emily, Anne, and Branwell Brontë, and by Louisa May Alcott with her sisters. See Margot Peters, Unquiet Soul: A Biography of Charlotte Brontë (London, 1975), pp. I 8-22; Martha Saxton, Louisa May: A Modern Biography of Louisa May Alcott (Boston, I977), pp. I6I-163, I78.

8. Handwritten newspapers were also quite common in Swedish popular movements, but they have been studied even less than the Finnish material. Ronny Ambjörnsson has analysed the paper Satir och allvar (Satire and Serious) edited in a temperance society of a sawmill community of Holmsund in the I920s; Ambjörnsson, Den skötsamma arbetaren, pp. I4I-I47, I6I-I73.

9. Ritva Haavikko, "Kirjoittavat lapset. Huomioita kirjailijaksi kasvamisen psykologisista ja sosiaalisista edellytyksistä”, in Henni Ilomäki et al. (eds), Salaamatta (Helsinki, I998), pp. I8721 8, I99-200.

ı०. Olavi Junnila, "Autonomian rakentaminen ja kansallinen herääminen”, in Suomen Historias (Espoo, I986), pp. I I-168, 106-108; David Kirby, A Concise History of Finland (Cambridge, 2006), p. I02; Matti Klinge, Ylioppilaskunnan historia. Toinen osa (Porvoo, 1967), p. I I.

I I. Klinge, Ylioppilaskunnan historia, p. I I. 
The last decades of the nineteenth century were a period of many reforms and great progress in Finnish society, economy, literature, and the press, ${ }^{\mathrm{I} 2}$ but that did not mean handwritten newspapers vanished, although they no longer served the same political and communicative purposes as they did during the I850s. In fact, their heyday began during the last decades of the nineteenth and at the beginning of the twentieth century in the agrarian youth movement, the temperance movement, and the labour movement, when thousands of issues were edited in hundreds of communities throughout Finland. ${ }^{13}$ Handwritten newspapers provided opportunities for important discussions and fierce debates. ${ }^{\text {I4 }}$ The labour movement adopted this tradition at the beginning of the twentieth century and it spread to new groups and communities. ${ }^{\text {Is }}$

I conclude that the manuscript medium (handwritten newspapers) was still an independent form of expression in early twentieth-century Finland, although it existed in close interaction with printed media and the oral tradition. The first point of my argument is based on the popularity of handwritten newspapers during the period. They were not a marginal genre, but were expanding into new social groups and local communities. The second point of my argument lies in the typical means of expression in handwritten newspapers. Those means of expression were linked to the history of the manuscript medium but still visible in the papers written in Finland at the beginning of the twentieth century. New groups which took up that tradition did not simply adopt the basic idea of writing a journal by hand, but the genres and expressive formulae, too.

A typical genre in newspapers handwritten at different times and in different communities is a "local-event narrative", which was a description of an event in a local community: an excursion, a meeting, a social evening, or a festival. ${ }^{16}$ Local-event narratives provide good examples of fictionalization, which I have outlined as one of the main narrative strategies in handwritten newspapers. Although the topics of the narratives are simple,

I2. Kirby, A Concise History of Finland, pp. I05-I23; Matti Klinge, A Brief History of Finland (Helsinki, I999), pp. 72-77.

I3. The most active year for editing handwritten newspapers in temperance societies was 1904, when I,I 29 issues were edited in 75 societies; Vihtori Karpio, Raittiuden ystävät I883-1933 (Jyväskylä [etc.], I938), p. 450 . According to statistics presented by Santeri Alkio, handwritten newspapers were edited in 238 agrarian youth societies in 1902; Santeri Alkio, "Katsaus suomalaisten nuorisoseurojen toimintaan 1902", Suomen Nuorison Liiton albumi III (1903), pp. 89-101, 95.

I4. Jaakko Numminen, Suomen Nuorisoseuraliikkeen historia I. Vuodet I886-1905 (Keuruu, I96I), pp. 459-47I.

I5. Jari Ehrnrooth, Sanan vallassa, vihan voimalla. Sosialistiset vallankumousopit ja niiden vaikutus Suomen työväenliikkeessä 1905-19I4 (Helsinki, I992), pp. 365-483.

I6. "The local-event narrative" can be compared with the "personal-experience narrative", which has been discussed by Sandra Dolby Stahl in Literary Folkloristics and the Personal Narrative (Bloomington, IN, 1989). 
their writers utilize various literary methods - narration, metaphor, and literary citation - in order to fictionalize their own experiences.

Localization, on the other hand, includes different means of rewriting and reinterpreting printed texts in a local context. Even texts copied word for word from a printed book or journal gain different meanings when republished in a local community. The process is comparable to the localization of oral narratives, which, according to the Finnish folklorist Lauri Honko, ${ }^{17}$ means adaptation of an oral narrative, often a historical legend, to a new setting and physical milieu where it did not originally belong. Rewriting a printed text into the manuscript medium is, in my opinion, a more conscious activity than adaptation of oral narratives. ${ }^{18}$

Handwritten newspapers were not just copies and imitations of printed texts, they were also a medium that enabled and encouraged literary creativity and experimentation. Writers of handwritten newspapers utilize open endings, meta-narrative comments, and complex narrative structures in a manner that often appears unconventional, even avant-garde in comparison with the printed texts of the time.

\section{IRONY, PARODY, AND SATIRE: DISCUSSION AND DEFINITIONS}

Mikhail Bakhtin outlines parody as "an intentional dialogized hybrid" compounded of linguistic and stylistic orders. Two languages come together and cross-pollinate one another: the language that is parodied (sublime style) and the language that parodies (low prosaic language). ${ }^{19}$

Parody is characteristic of the genres, paratexts, narrative structures, and even the layout of handwritten newspapers. Writers of such papers often attempted to create the illusion of a printed paper with elaborate layout and journalistic style, and the paratexts - titles, dates, cover pictures imitate printed papers in a parodic manner. Parodism is embedded in the narrative structures of handwritten newspapers. Often, texts were written

17. Lauri Honko discusses two forms of milieu-morphological adaptation of oral tradition: familiarization means adaptation of oral narratives to familiar natural settings; localization means "linking a certain tradition to a spot or place in the experienced physical milieu". The theoretical framework for these terms is the ecology of tradition; Lauri Honko, "Four Forms of Adaptation of Tradition", in idem and Vilmos Voigt (eds), Adaptation, Change and Decline in Oral Literature (Helsinki, I98I), pp. 19-34, 19-21.

I8. Comparable phenomena of copying and rewriting were typical of the manuscript culture in the early modern period. James Bristol and Arthur Marotti have described manuscript communication as a literary environment in which "texts were malleable and social rather than fixed and possessively individualistic"; James Bristol and Arthur Marotti, "Introduction", in idem (eds), Print, Manuscript and Performance: The Changing Relations of the Media in Early Modern England (Columbus, OH, 2000), pp. I-32, 5 .

19. M.M. Bakhtin, The Dialogic Imagination: Four Essays (Austin, TX, I981), pp. 75-76. 
as if the paper were a "real" newspaper with a circulation, and in which writers and readers would be unknown to each other.

Parody is a powerful element in both the oldest and the most recent handwritten newspapers: the young writers of the earliest family papers of the early nineteenth century and writers of school papers of the late twentieth century each parody the genres of the printed media. Parodic news and advertisements occurred frequently even in the more seriousminded handwritten newspapers serving the popular movements of the early twentieth century, even though frequently they occupied only a modest space at the end of the paper along with the anecdotes. In Finnish popular movements, especially in societies for young people, a genre of "parodic minutes" was popular. Sometimes they developed into detailed observation reports on "what really happened" in meetings, standing apart from the official programme. ${ }^{20}$

I have observed in my research material two kinds of parody, which are often intermingled: ideological parody (or satire) is directed against political opponents (the bourgeoisie, the Church, the workers of the older generation) and the texts representing their ideology; generic parody involves playing with linguistic norms and generic conventions.

Ironic expressions in handwritten newspapers are related to social and emotional tensions in the communities where they were written and published. The writings of Linda Hutcheon are inspiring for the analysis of the politics of irony. According to Hutcheon, irony, with its "evaluative edge", differs from metaphor or allegory, and provokes "emotional responses in those who 'get' it and those who don't, as well as in its targets and in what people call its 'victims"”. ${ }^{21}$ Irony provides means for discussing the tensions in groups and the delicate emotions of inclusion and exclusion. ${ }^{22}$ Irony, parody, and satire are often intertwined in the same texts and their coexistence creates numerous possibilities for interpretation.

In her recent study, the Finnish linguist Toini Rahtu criticizes the overemphasizing of the negative aspects and the "victims" of irony. ${ }^{23}$ I came to similar conclusions in my own study: the irony in question does not always denigrate the "targets" nor ridicule the "victims" whether inside or outside the ironist's own group, but it can create perplexity and curiosity among readers and listeners who, if the irony were not understood, might be offended by a text and refuse altogether to read or listen to it. Irony can make certain stories tellable, and certain messages deliverable. Furthermore, it can provide protective "narrative estrangement" for the author.

The other main point emerging from Linda Hutcheon's study is the

20. Salmi-Niklander, Itsekasvatusta ja kapinaa, p. I I 4.

2 I. Linda Hutcheon, Irony's Edge: The Theory and Politics of Irony (London [etc.], I995), p. 2.

22. Ibid., p. 43 .

23. Toini Rahtu, Sekä että. Ironia koherenssina ja inkoherenssina (Helsinki, 2006), pp. 50-5 I. 
close bond between the type of irony, the community, and the local culture. ${ }^{24}$ This bond makes irony more difficult than parody to recognize and interpret. Ironic expressions can be interpreted on the basis of their linguistic properties, hyperbolic expressions, illogicalities, and inconsistencies. Irony can be recognized in relation to other texts or discourses cited, referred to, or contested in the text analysed. The recognition of ironic meanings in oral-literary local tradition obviously requires knowledge of the historical context of the community, and even the personal histories of its members.

\section{THE YOUNG WRITERS IN A TOWN CAST IN IRON}

Valistaja (The Enlightener, see Figure I) has an exceptional history. The paper was confiscated by the police in 1926 because of the communist political orientation of its writers. It was only at the beginning of the $1980 \mathrm{~s}$ that a pile of issues of Valistaja were found in the attic of the local police station.

Valistaja was a huge literary effort for a small group of young people in an outlying community without much literary tradition. The preserved collection runs to 550 pages and is probably only about half of the original material. The Finnish historian, Kimmo Rentola, has pointed out that the parish of Pyhäjärvi, where the Högfors ironworks was founded in I 820, was an isolated community, even though it is only seventy kilometres north-west of Finland's capital, Helsinki. Road connections were poor, but a narrow-gauge railway was built from Högfors to Hyvinkää in I 9 I I. The traditional soothsaying and cultivation using fire were still practised in Pyhäjärvi at the beginning of the twentieth century, and the majority of adult men still made marks instead of writing signatures on official documents. ${ }^{25}$

The authors of Valistaja, young unmarried men and women in their late teens and early twenties, were the first fully literate generation of their families and their community. They were therefore able to use writing not just for simple practical purposes, but as a means of expressing thoughts and emotions. That generation had experienced many rapid changes during their childhood and youth, among them the expansion of the Högfors ironworks into the largest of its kind in Finland and the establishment of the workers' movement and the primary school system during the first decade of the twentieth century. ${ }^{26}$

24. According to Hutcheon, irony is produced in discursive communities in which the members share both the presuppositions of communication and its relationship with "identity, position and relative social status of the participants"; Hutcheon, Irony's Edge, pp. 98-99.

25. Kimmo Rentola, "Karkkilan historia. Toinen osa", in Seppo Aalto and Kimmo Rentola (eds), Karkkilan historia (Karkkila, I992), pp. 274-284, 394-399, 440-44I.

26. Ibid., pp. 440-44I, 467-469, 518-526. 


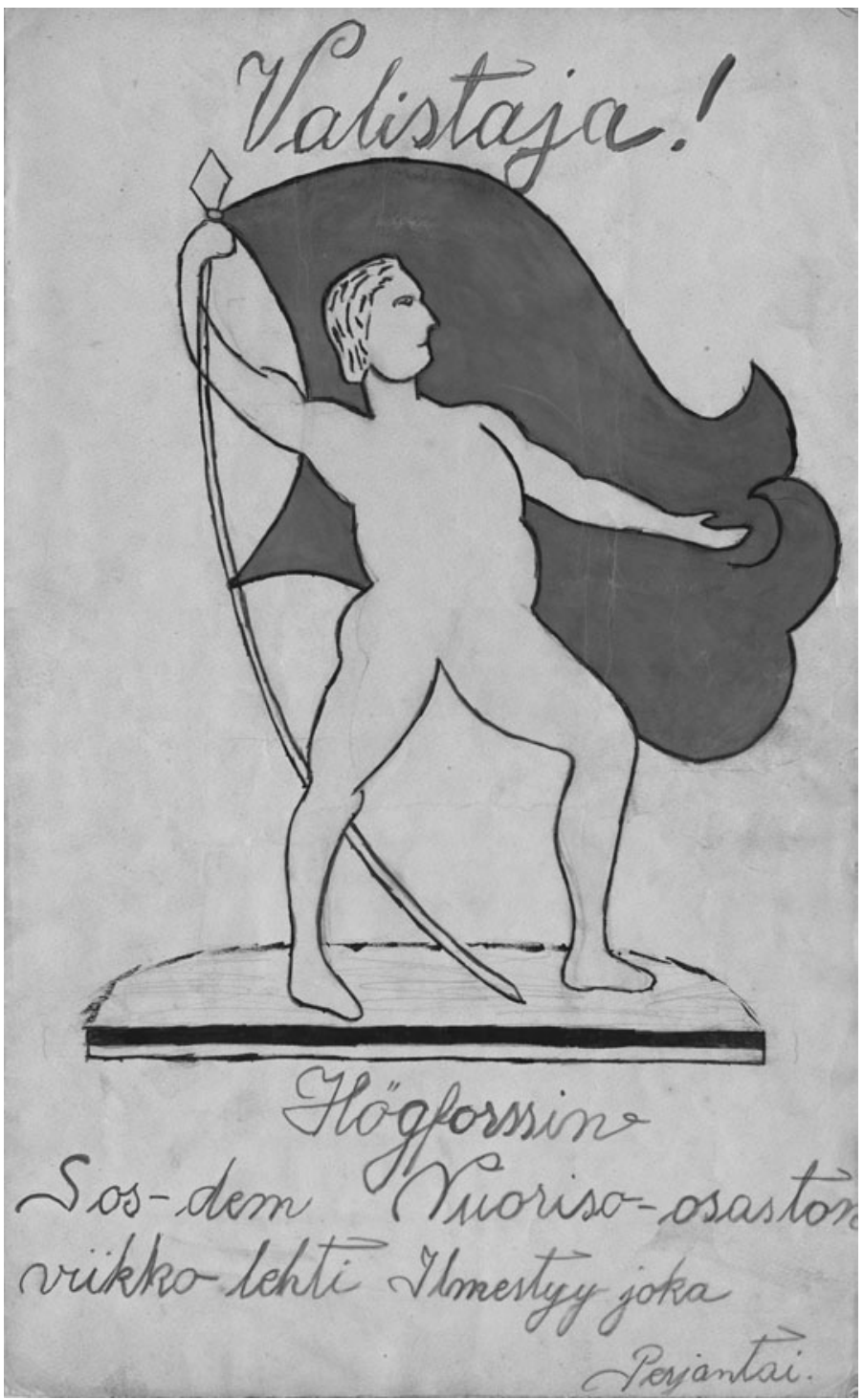

Figure I. Many handwritten newspapers were elaborately illustrated, but only a few issues of Valistaja had pictures on the cover. On the cover of the 22 April I92 I issue an androgynous figure is holding a red flag.

Finnish Labour Archives. Used with permission

A traumatic experience common to all that generation was the Civil War, which had a unique result in Karkkila. The Red Guard assumed power in the town and the factory, since before the Civil War the White Guard could not be established. German troops, after they landed on the 
south coast of Finland at the beginning of April I9I 8, went on to decide the Civil War in the White Guard's favour. When the Germans captured the railway station at Högfors, the local Red leaders concluded an armistice with them. Later, that armistice was betrayed and many Red leaders were executed or died in prison camps. ${ }^{27}$

One more exceptional feature of Valistaja was the active role of young women in writing the paper. That is a surprising phenomenon in relation to the strict gender system of Karkkila: the ironworks employed men exclusively until the I920s and women were economically entirely dependent on their husbands. The wives of the workmen had an essential though unpaid position in the economy, spending a large part of their day carrying and heating water so that their husbands and sons could wash after work. ${ }^{28}$ For most members of it, their time in the youth club lasted only a few years, but it was an important period in their lives during which they were looking for a spouse and making life choices, albeit very limited ones. The boys would go to the foundry, often to the same department where their father worked; the girls would work as maids or on the farm owned by the ironworks, then they would expect to be married and continue housework in their own home.

The articles in Valistaja deal with a great variety of topics, including local association activities, national and international news. The writers make use of a great variety of genres adopted from literature, the press, and the oral tradition. Most texts were written anonymously or under a pseudonym, a common habit in handwritten newspapers. Pseudonyms could be feminine (Rebekka, Vagrant Girl), masculine (Justus, Vagrant Boy) or gender-neutral (Comrade, Observer, Worker, Thinker, Pen). In small communities readers or listeners could probably guess who the writer of each text was, but for me the pseudonyms have caused complicated detective work in my research. Since only a few texts were signed by their writers, I have had to compare the handwriting in issues of Valistaja and in the minutes of the youth club to discover the identity and the literary profile of the writers.

The papers were published by being read aloud to weekly "meetings with a programme". In those meetings members of the club performed songs, poems, and short stories. The performances were discussed and evaluated by the audience, and performers were given grades, rather like in school. Such apparently non-political activities were useful to attract audiences to the agitation tours made by the young socialists of Karkkila to neighbouring villages.

27. Kimmo Rentola, “The Red Karkkila”, in Sakari Hänninen et al. (eds), Meeting Local Challenges - Mapping Industrial Identities (Helsinki, I999), pp. I08-I I I, I26-I 27.

28. Kirsti Salmi-Niklander, "Soot and Sweat: The Factory in the Local Tradition of Karkkila", in Hänninen et al., Meeting Local Challenges, pp. I30-I43, I37-I39; Salmi-Niklander, Itsekasvatusta ja kapinaa, pp. 364-365. 


\section{PARODIC SPEECHES AND NEWS}

The following examples of parodic texts from Valistaja depict the interplay of ideological and generic elements. All the texts were published during the period of political radicalization at the beginning of the I920s, when the young people of Högfors adopted the communist ideology in the division of the Finnish labour movement, and convinced the older generation of workers of the superiority of the communist position. This political event has affected local history right up until today, and the town is still known as "Red Karkkila". ${ }^{29}$

"The speech of a patriotic bourgeois to the civil guard" was published on I I February I92 I under the pseudonym "The Observer". It was probably written by Väinö Ảberg (I 899-I 923), who was a leading figure among the young socialists in Karkkila after the Civil War. He became a kind of martyr to the young radical workers after his early death from lung disease. The target of the irony and parody is obvious, since the narrator delivers his "speech" to the Civil Guards, a local paramilitary organization founded before the Civil War but officially sanctioned only after the victory of the Whites. $3^{\circ}$ As in early modern parodies analysed by Bakhtin, the parody is created in the opposing of noble rhetoric to vulgar language:

Oh you brave elite troops, who did not hesitate when we fought against the Reds. How noble you were, when you made short work of the Reds, after the Germans had first taken them prisoner. [...] You avenged the tears of your wives, you did not listen when the women of the Reds prayed for those crooks. You made short work of it. If any woman started jabbering too much, you gave her the same passport; what could have been simpler than ordering the missus to his side [i.e. her husband's] then shoot her down into the same pit as her man. ${ }^{3 \text { I }}$

The memories of the Civil War were distressing, and the young writers of Valistaja hardly touched on their personal experiences at all, nor on events in Karkkila itself. Even though this parodic speech does not refer directly to anything that occurred locally, it depicts Whites as cowards hiding in "damp cellars and snowy forests" who began executing Reds only after the Germans had won the war for them. In Karkkila one of the most traumatic and little talked of events after the Civil War was that some sons of working-class families joined the White Guards and participated in executions of Reds..$^{22}$

The following piece of "news" was published in Valistaja on 3 I March

29. The members of the Högfors Social Democratic Youth Club took this ideological turn in May 1920, when they decided to join the Communist Youth International; Rentola, "Karkkilan historia. Toinen osa", p. 8is.

30. Kirby, A Concise History of Finland, p. I63.

31. Salmi-Niklander, Itsekasvatusta ja kapinaa, p. 209.

32. Ibid., pp. 204-205. These memories are still distressing and I had to promise my informants not to reveal the names of men who had killed their neighbours and school friends. 
I92I, when the debate on communism and social democracy was at its most heated:

A telegram from Moscow has been rushed to us on the IIth day of this month. The operations of Allied forces have developed so terribly fast that we already seem to be in the noose. The French navy is at the gates of Moscow, ready to attack the city; tanks and armoured trains run by Allied forces are cruising on the Black Sea preparing to occupy south Russia any moment.

In northern parts of Russia too, operations have been hectic, with disastrous results on both sides. An English tank and an American submarine crashed outside Kronstadt and both were instantly destroyed. A Russian armoured train and an aeroplane piloted by the Allies collided right outside St Petersburg, too. The train was completely destroyed but the aeroplane got off with a fright and was able to return to base. So serious is the news right now. ${ }^{33}$

This piece of "news" is an example, then, of the generic type of parody. It does not just play about with impossibilities, but is inconsistent with the ideology of the writers: why would they ridicule the struggles of the young Soviet Union and parody the style of a Soviet reporter? The explanation of this inconsistency lies probably in the importance of humorous genres in socialist agitation. The labour movement had its own comic magazines with anecdotes, cartoons, and parodic news. A good socialist was supposed to be able to make a joke on practically anything, even at his or her own expense.

\section{OLD GENRES, NEW MEANINGS}

Parodic expressions in handwritten newspapers of the labour movement were related to contemporary journalistic genres, news, and advertisements, and had intertextual links to the genres of popular parody in the oral tradition. The labour movement adopted a traditional genre of mock "sermons" and gave them a new ideological content. "The porridge speeches" were performed at Christmas festivals organized by the labour movement as an alternative to Church ceremonies. ${ }^{34}$

Some of the "porridge speeches" were, apparently, published in handwritten newspapers. That is probably the case with the text "The Fellow of Bethlehem" (2 February 1922). It was written by seventeenyear-old worker Paavo Saaristo, who became one of the most influential writers of Valistaja in the I920s. However, I have been able to trace his literary activities only by comparing handwriting, since he shared the pseudonym "Observer” with Väinö Aberg.

"The Fellow of Bethlehem" is a text amenable to many interpretations.

33. Ibid., pp. I $52-153$.

34. Ulla-Maija Peltonen, Punakapinan muistot. Tutkimus työväen muistelukerronnan muotoutumisesta vuoden I9I8 jälkeen (Helsinki, I996), pp. 218-219. 
The language comes close to the spoken word, as if this speech would have been presented to fellow workers in the lunch break at the ironworks. Apparently, this text parodies the Biblical story of the birth of Jesus, relating it to contemporary events. The writer lampoons the myth of the virgin birth of Jesus by describing Joseph as "a half-crazy man" who is persuaded by the maiden Mary to become a father to her illegitimate child. The secularization and degradation of the life story of Jesus is contrasted with the identification of the narrator with him. This identification was based on local tradition, since one of the departments in the ironworks was called "Bethlehem":

No, we talk about a fellow who did not want to work, he was quite lazy, he begged and starved although his father trained him as a carpenter. [...] Already as a child it was noticed that he would never become a worker, but he was left to grow up in freedom. He became an agitator and a good one indeed, since all the people followed him on long journeys and listened to him with their mouths wide open. 35

These were daring words to be said and written in a patriarchal industrial community, where young men followed their fathers to the ironworks to learn their trades. The struggle over working hours at the beginning of the I 920 s created a rift between older and younger workers, for the older ones found it difficult to get used to an eight-hour working day, which in Finland had been achieved in I 919 after a long struggle. They mocked the younger men, calling them lazy and spoiled, and the young ones accused their fathers of kowtowing to the owners and their foremen. ${ }^{36}$ "The Fellow of Bethlehem" is an address in this debate, although it is doubtful that it was ever presented to the working community in the ironworks.

\section{AN ODYSSEY OF THE FACTORY BOYS}

A close reading of Valistaja and other documents of the youth club reveals that the cooperation of young men and women was, in fact, a constant seesawing between dialogue, silencing, and resistance. During the early years from I9I4-I9I7 young women became active writers and editors of the paper, and they brought questions of love, emotions, and gender identity to the discussions. This tendency was even stronger after the Civil War and the period of political radicalization during I9I9-I92I. The year I 922 saw a kind of backlash against the young women in the youth club: the girls felt harassed in the meetings and complained that the boys "never talked about anything else than booze". Prohibition in I9I9 succeeded in making

35. Quoted by Salmi-Niklander, Itsekasvatusta ja kapinaa, p. 295.

36. Ibid., pp. 291-296; Kari Teräs, Arjessa ja liikkeessä. Verkostonäkökulma modernisoituvan työelämän subteisiin (Helsinki, 2001), pp. 89-99. 
alcohol even more tempting to the young men than it had been before. For a while, almost all the girls left the club, many of them for good. One of the last achievements of Väinö Åberg before his early death was to mediate between the young men and women. ${ }^{37}$

The narrative strategies of fictionalization and localization too are related to gender. According to my observations, fictionalization was a more common narrative strategy among the young male writers, who described their own experiences with a narrative distance. The young women writing to Valistaja often utilized texts adopted from printed sources, but they were localized by changing some details of the story so that they could have taken place in Högfors.

During the last three years when Valistaja was published (I922-I925), the factory boys "took over" the paper with their travel stories, lengthy descriptions of excursions to neighbouring towns and villages, or to the capital Helsinki. Probably only fragments of these stories (which I have named "An Odyssey of the Factory Boys") have been preserved. Most of them were written on loose sheets which I have been able to date from their content. However, this narrative entity is a remarkable example of literary creativity and the interplay of orality and literacy in handwritten newspapers..$^{8}$

The writing of travel stories was inspired by challenges that were published in the paper. Members of the club challenged each other to write openly and in detail about their experiences and adventures. Subjects given for these challenges could be, for example, "Alcoholism", or "How I spent the First of May". In an issue of April I 925 a writer appeals to the readers after presenting several challenges to certain members: "Accept your challenge as honourably as those comrades who have fulfilled their duty and sit in the prison of Turku at the moment." This comment refers to the treason trials against young communists, which were going on in several places in Finland at the time. The members of the Högfors Social Democratic Youth Club were very cautious in their activities since even the most apparently innocent social evenings or picnics could lead to prosecution for treason. They retained the words "social democratic" in the name of the club, even though it was far from their ideological position at the time. 39

The pompous challenges stand in ironic contrast to the actual content of the travel stories. The ideological tendency in these stories is vague. Often

37. Salmi-Niklander, Itsekasvatusta ja kapinaa, pp. 274-283. The effects of the prohibition on Finnish folk culture have been studied in Satu Apo, Viinan voima. Näkökulmia suomalaiseen alkoholiajatteluun ja-kulttuuriin (Helsinki, 200I), pp. 213-2 I4.

38. Salmi-Niklander, Itsekasvatusta ja kapinaa, pp. 327-330.

39. Ibid., pp. 327-328. On the treason trials see Jaakko Mäkelä, "Oikeudenkäyttö Suomen politiikassa: valtiorikosjutut i918-1939”, Politiikka (1976), pp. 303-316, 311-313; Tauno Saarela, Suomalaisen kommunismin synty 1918-1923 (Helsinki, I996), p. 356. 
the official purpose of the journey - a wrestling match, a drama performance, or an agitation tour - is passed over rapidly, or the travellers barely make it to their destination. Instead, the writers describe in great detail the journey itself: the relationship between the travellers, their quarrels and discussions, eating and drinking, even urinating. The only topic that is discussed only modestly is sexuality. Probably the reason for this discretion was that these stories were actually read aloud to young women.

According to the handwriting, many of the travel stories were written by Paavo Saaristo. Apparently, the original stories had been narrated by several of his friends, but as a skilful writer he helped write their stories (see Figure 2). The travel stories construct a complex narrative network, with the same characters appearing in more than one story and the same events perhaps described differently by different writers. The language of the travel stories is very difficult to translate, since it is replete with dialogue, expressions in the local dialect, and with ironic references to political and religious language and citations of popular songs. This language can be described as a kind of "collective stream of consciousness" of the young factory boys. The narration has the tone of an immediate experience and unpredictable events.

We can find a good example of this game of narrative hide-and-seek in a two-part story entitled simply "A wrestling tour", which was published probably in I925. The travelling group consists of four young men, whom the narrator has renamed, according to their fighting weight category, as "Heavyweight", "Lightweight", "Flyweight", and "Featherweight". He blends into the group by utilizing "the narrative we", which is common in local event narratives. Only through careful close reading can it be deduced that the narrator is actually "Lightweight", even though he refers to himself in the third person. The tension of the story is created by the weights of the young men, for as they make their way to the wrestling match, three of them are trying to lose weight to qualify for the right category. They are doing so by fasting, walking around looking at the sights in Helsinki, and going to a public sauna bath several times.

For a short period the narrator changes his viewpoint to observe the travellers from above: "Four hungry vagabonds trudged the streets of the city carrying in turn a large lunch bag, they marched decisively towards the great purpose which had settled in their minds now - the sauna." The expression "the great purpose" is an ironic reference to socialist language. This citation reveals also the irony in the setting of the story. The hungry wrestlers have to carry Heavyweight's lunch bag. He is the only one who does not need to lose weight, but he puts the greatest pressure on his comrades. The famine during the Civil War was still present in the bodies as much as the memories of these young men, which makes the irony of the setting even more telling.

At the end of the second part of the story the wrestlers finally reach their 


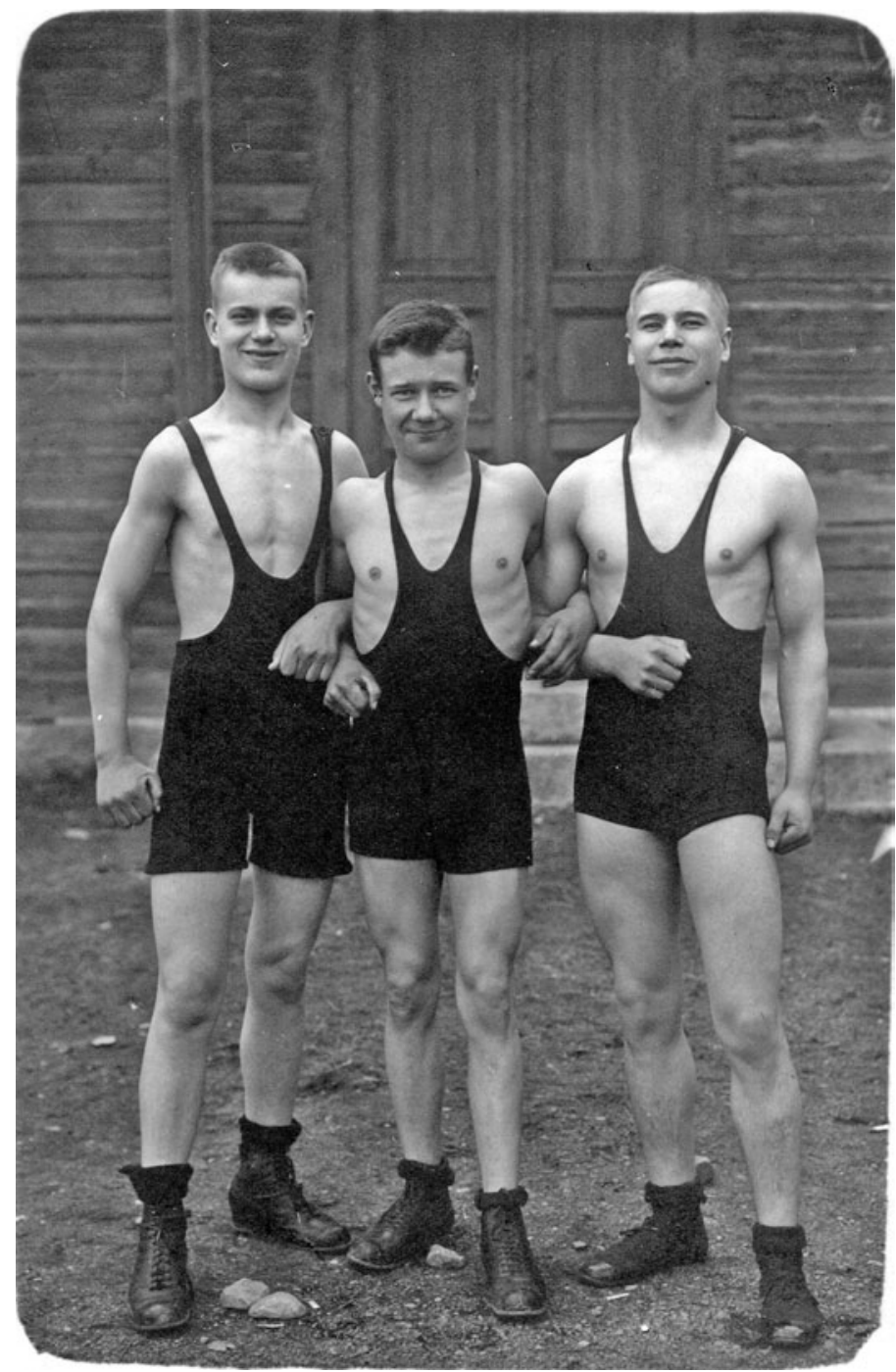

Figure 2. Wrestling became an important activity for the young men in Högfors in the I 920 s. Paavo Saaristo (right) is posing with his friends Huugo Nieminen (middle) and Juho Kusti Virtanen (left).

Private collection of Reino Luoto. Used with permission

destination, a workers' hall on the outskirts of Helsinki where the match is to take place. The unlucky Featherweight is still overweight and has to compete in another weight category. "It is good that Featherweight was quiet, but Heavyweight reminded him of his mortality", comments the narrator. We do not know what happened in the match, since the third part 
of the story has not been preserved, or maybe it was never even written. Most of the travel stories remain similarly open-ended.

\section{A FLANEUSE}

The young women writing to Valistaja hardly ever responded to the challenges to describe their own experiences. However, the young girls actually wrote the first travel stories during the early I920s, before the boys "usurped" this narrative genre. Instead of revealing their experiences and emotions, the girls hid behind even more complex narrative positions and ironic expressions, much more so than the boys. The travel story "When I walked on the "Leksi"” was published in Valistaja on 22 April I92 I. The pseudonym is "Tuulihattu", which comes close to the English expression "flibbertigibbet" or "giddy girl", and the text was written - or copied and localized - by a young woman. $4^{\circ}$

"Leksi" in the title is a slang expression for Aleksanterinkatu (Alexander Street), one of the main streets in Helsinki. ${ }^{\mathrm{I}}$ This story is presented as a first-person narrative of personal experience in which a young girl from Högfors tells about her adventures in Helsinki, but it is rather a "pseudopersonal-experience narrative" fictionalized in a pseudo-dialect: the story is not written in the dialect of Karkkila but that of Rauma, a city on the west coast of Finland, and is spiced with some words of Helsinki slang. The dialect of Rauma had by 1920 been established as "a literary dialect", since many stories using it had been published in printed publications. The story begins:

I once went to walk on the "Leksi" as the big girls are in the habit of doing. It is one of those places where people go to get picked up. Two gentlemen walked behind us, they were all dressed up and their trouser legs were as wide as sails. I thought that one does not see such men here in Högfors. I waited and waited to see if those gentlemen would pick us up. I had an idea that picking up means they grab your collar and start fighting. The girl who was with me cast encouraging glances to the men behind us and looked back every now and then. So I followed her example and straightened out my collar which I had placed over my coat for picking up. At last one man came posing beside me and the other went like a whirlwind with my friend who was a real city girl. The man who came to me started to talk like this: I think I have seen you before, miss. I said that's quite possible, then he said that we should go to a café, it's all the same to me said I.

This text is much more daring than any of the boys' travel stories in its discussion of (possible) sexuality. The narrative estrangement which made

40. The story is written in the handwriting of Alli Laine.

4I. The dictionary of Helsinki slang (Paunonen Heikki and Paunonen Marjatta, Tsennaaks stadii, bonjaaks slangii. Stadin slangin suursanakirja (Helsinki, 2000)) does not include this word. According to the dictionary, the slang expression for Alexander Street is simply "Aleksi". 
the presentation of this story possible lies both in the "pseudo-dialect" and in the position of the narrator, a girl from Karkkila. She is "an unreliable narrator", since she is pictured as wanton, and ignorant about modern city life. ${ }^{42}$ Later in the story her ignorance creates comic situations. At the end she goes to the cinema with the gentleman, who according to his costume belonged to a group named sakilaiset or "hooligans", the first urban subculture in Finland. ${ }^{43}$ When a man on the screen points a gun at her, she starts screaming and runs away to catch the last train back home to Högfors. The purpose of this story was probably both to amuse the girls and tease the boys of Karkkila with the remarks about the handsome young men of Helsinki. At the same time, the writer escapes moral judgement by the use of irony and narrative estrangement.

This story is unique. Other travel stories written by young women are much more cautious, and in most of them the narrator is a neutral observer or commentator. Travelling, even to visit the local railway station or a trip to a neighbouring village, was, apparently, a dangerous activity for young women. ${ }^{44}$ Many feminist researchers have observed similar caution in the travel stories written by women during the nineteenth and early twentieth centuries, pointing out the masculinity of the figure of the "flaneur", an idle observer of urban life and one of the great icons of "modernity". ${ }^{45}$ The young male flaneurs of Högfors could be depicted as ridiculous and pitiful characters, but a flaneuse from a working-class town risked her morals and reputation. In the pseudo-dialect story a female writer creates a comic and fictional figure of a flaneuse, who may be wanton and ignorant but, nevertheless, enjoys her experiences of city life and in the end returns home unharmed.

\section{CONCLUSIONS}

The uses and meanings of irony and parody are related to political events, changes in local mentality, and personal experience. Parody and satire could expose the cruelty and cowardice of the Whites, skewer the hypocrisy of the Church, and mock the conservatism of the older generation. But expressions laden with irony always seem rather to reflect the group's own tensions, or emerge from the varied experiences of young people in Karkkila.

42. According to Shlomith Rimmon-Kenan, an unreliable narrator is a narrator whose "moral values are considered questionable"; Shlomith Rimmon-Kenan, Narrative Fiction: Contemporary Poetics (London [etc.], I983), p. гог.

43. Kari Koskela, Huligaanit. Katuelämää Sörkassa suurlakosta sisällissotaan (Helsinki, 2002).

44. Salmi-Niklander, Itsekasvatusta ja kapinaa, pp. 318-319, 348-349.

45. Rita Felski, The Gender of Modernity (Cambridge, MA [etc.], I995), pp. I6-i7; Janet Wolff, Feminine Sentences: Essays on Women and Culture (Oxford, 1990), pp. 34-50. The travel stories of Finnish women writers have been analysed by Ritva Hapuli in Ulkomailla (Helsinki, 2002). 


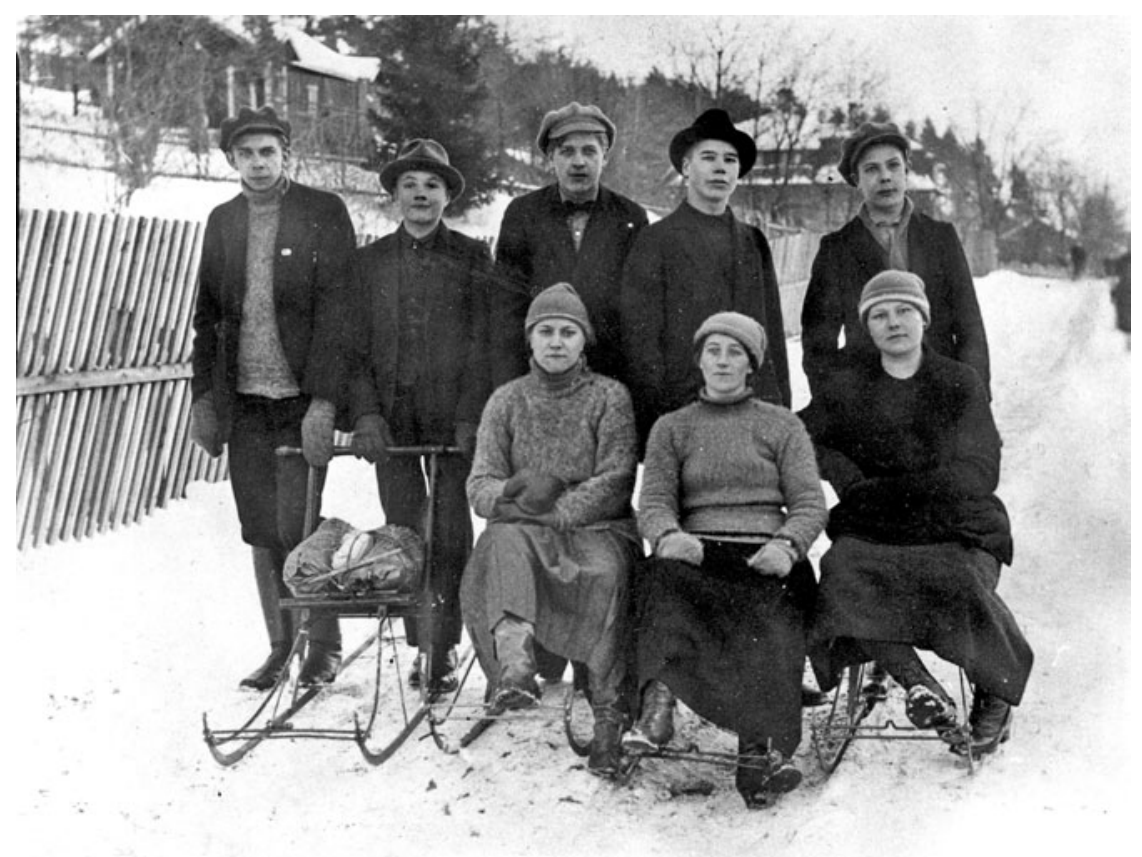

Figure 3. Outings with kick sleds were a popular wintertime activity for the young people in Högfors. Väinö Aberg is first on the left, Paavo Saaristo second from the right standing, Lyydia Virtanen first on the left seated.

Karkkila Ironworks Museum. Used with permission

After the defeat and betrayal of the local Red leaders in the Civil War, young people took the political initiative in their communities. At the same time as the young writers of Valistaja were parodying and ironizing the labour movement's ideals of self-discipline, they were also risking their freedom, even their lives, for the socialist cause. However, in the end only a few of the young people in Högfors were ever imprisoned for their political activities. Probably, the young men of the community were protected by their positions as skilled workers, and they were tied in any case to their homes, the ironworks, and to the local community itself. Their feelings of anxiety and the longing for freedom were expressed in their stories of travel, although they no doubt reflected the withdrawal of the young factory boys to their own homosocial world.

The young writers of Valistaja referred to the Civil War with the expression "bitter memories", which they felt obliged them to seek revolution and revenge. When discussing the inner tensions of their own community they used the metaphorical expression "burst soap bubbles". The soap bubbles stood for the cooperation between the young men and 
women and their creation of a new kind of community: a project doomed to collapse during the early I 920 ..$^{46}$ Many of the active young women who left the youth club in 1922 remained unmarried for the rest of their lives, stayed at home, or moved away from Högfors. One of them was Lyydia Virtanen (I90I-I974), a tailor who suffered political imprisonment from I929-I93 I and later for many decades was an important leader in Karkkila. ${ }^{47}$ Paavo Saaristo too (1905-1970) became a key figure in "Red Karkkila" and was a long-standing chairman of the city council (see Figure 3).

During those eleven years while the young people of Karkkila were writing Valistaja they developed as a conversational community, and learned to make use of different means of oral and literary expression. I have come to a somewhat surprising conclusion that the elements of oral tradition were strengthened in their texts during the I920s. Instead of merely adopting existing literary language and genres, they created new hybrid expressions from the various oral and written languages available to them. Irony and parody, fictionalization, and localization provided means for playing with the hazy boundary between experience and fantasy, the limitations of everyday life, and possibilities for change. 